\title{
IMPACT INVESTMENT IN MARINE CONSERVATION
}

\author{
Nicolas Pascal, ${ }^{*}$ Angelique BrathWAite, ${ }^{* *}$ \\ MAXIME PHILIP, ${ }^{+} \&$ MELISSA WALSH ${ }^{++}$
}

\section{EXECUTIVE SUMMARY}

Coral reefs provide exceptional biodiversity and ecosystem services for local economies. Well marketed, vibrant marine biodiversity has been demonstrated to generate substantial economic benefits for local populations through revenues from visitors and businesses. However, around one fifth of the world's coral reefs have already been lost, and more than $60 \%$ are reported to be under immediate and direct threat. Marine Protected Areas (MPAs - marine zones with specific regulations for different uses) are among the most effective tools in the scientific literature used in the protection of threatened reefs. To be successful though, MPAs (and other forms of marine conservation) require financing and management resources that can exceed public budget priorities.

During the last five years, a community of investors seeking positive social and environmental returns in addition to financial returns have stepped in to fill the marine conservation financing gap. These Impact Investors have invested over US\$8 billion since 2004 in food and agriculture, forestry, habitat protection, clean water initiatives, and other conservation projects. With respect to marine biodiversity, a small but positive track record of impact investments has confirmed the feasibility of achieving environmental, social and financial returns in tandem.

Recent reports also revealed that at least US\$3.1 billion in committed capital is sitting on the sidelines, awaiting attractive deals.

\footnotetext{
Copyright (C2018 Nicholas Pascal, Angelique Brathwaite, Maxime Philip, \& Melissa Walsh.

*Laboratoire d'Excellence (CORAIL) USR 3278 CNRS-EPHE, Centre de Recherche Insulaire et Observatoire de l'Environnement (CRIOBE), Moorea, French Polynesia; Blue Finance ECRE (Economics for Coral Reef Ecosystems), Foster Hall, Barbados.

${ }^{* *}$ Blue Finance Economics for Coral Reef Ecosystems (ECRE), Foster Hall, Barbados.

+ Laboratoire d'Excellence (CORAIL) USR 3278 CNRS-EPHE, Centre de Recherche Insulaire et Observatoire de l'Environnement (CRIOBE), Moorea, French Polynesia.

${ }^{++}$Pacific Regional Oceanscape Program, Office of the Pacific Ocean Commissioner.
} 
Blue finance, is a novel approach piloted by the United Nations Environment Program, which seeks to provide a diversified portfolio of investments through Public-Private Partnerships (PPPs) for the management of MPAs. In addition to generating financial returns through sound business models, PPPs can have positive social and environmental impacts, playing roles in restoring marine biodiversity, improving tourism and creating significant job opportunities in the tourism and fishery sectors.

\section{CONTEXT}

\section{A. Marine conservation and the financing gap}

Oceans contribute to human well-being by providing marine ecosystem services such as food, income, cultural services, recreation, carbon storage, and storm protection. ${ }^{1}$ The ocean's ability to continue providing these essential ecosystem services is in jeopardy primarily due to the anthropogenic impacts of climate change, fishing pressure, coastal development, pollution, and recreation. ${ }^{2}$ Numerous approaches and tools have been used to address these challenges, including, but not limited to, Marine Spatial Planning (defining a combination of different regulated areas), climate and marine pollution policies, and fishery management. ${ }^{3}$ Herein we use the inclusive term "marine conservation initiatives" to refer to all initiatives for management, restoration, sustainable use, and preservation of marine resources.

Marine conservation initiatives can be found on almost every country

1. See 1 Millennium Ecosystem Assessment BoARd, Ecosystems And Human WellBeIng: CurRent State AND TREnds 6-14 (2005); Stephen R. Palumbi et al., Managing for ocean biodiversity to sustain marine ecosystem services, 7 FRONTIERS ECOLOGY 204, 204 (2009); Winnie W.Y. Lau, Beyond Carbon: Conceptualizing Payments for Ecosystem Services in Blue Forests on Carbon and Other Marine and Coastal Ecosystem Services, 83 OCEAN \& COASTAL MGMT. 5, 6 (2013); Yann Laurans et al., Economic Valuation of Ecosystem Services from Coral Reefs in the South Pacific: Taking Stock of Recent Experience, 116 J. ENvTL. MGMT. 135, 136-37 (2013); Tobias Börger et al., Incorporating Ecosystem Services in Marine Planning: The Role of Valuation, 46 MARINE POL'Y 161, 161 (2014); Sandra R. Werner et al., Rapid Prioritization of Marine Ecosystem Services and Ecosystem Indicators, 50 MARINE POL'y 178, 180 (2014); Nicolas Pascal et al., Economic Valuation of Coral Reef Ecosystem Service of Coastal Protection: A Pragmatic Approach, 21 ECOSYSTEM SERVS. 72, 72-73 (2016).

2. See Boris Worm et al., Impacts of Biodiversity Loss on Ocean Ecosystem Services, 314 SCI. 787, 787 (2006); Benjamin S. Halpern et al., A Global Map of Human Impact on Marine Ecosystems, 319 SCI. 948, 948-49 (2008); Scott C. Doney et al., Climate Change Impacts on Marine Ecosystems, 4 ANN. REV. MARINE SCI. 11, 12 (2012); Benjamin S. Halpern et al., An Index to Assess the Health and Benefits of the Global Ocean, 488 NATURE 615, 615 (2012).

3. See Benjamin S. Halpern, Making Marine Protected Areas Work, 506 NATURE 167, 167-68 (2014) (arguing that five factors are necessary to a successful marine protected area); G. CARLETON RAY ET AL., Marine Conservation: SCIEnCE, Policy, AND MANAGEMENT 1-5 (2014) (noting the complex issues intertwining the different goals of marine conservation). 
on Earth. ${ }^{4}$ There are notable success stories where conservation objectives have been achieved and/or threats diverted ${ }^{5}$ but more often than not, the stories are of declines in marine resources and consequential impacts on human well-being, despite monumental efforts. ${ }^{6}$ The success of marine conservation initiatives is constrained by disjointed and inadequate ocean governance $^{7}$, conflicts between stakeholders ${ }^{8}$, limited enforcement capacity $^{9}$, and inadequate financing. ${ }^{10}$

Recent studies have confirmed that funding for protected areas and biodiversity conservation must increase significantly to achieve national (e.g. National Biodiversity Strategic Action Plans) or international targets (e.g. the 17 Sustainable Development Goals defined by United Nations). A top-down assessment conducted by the Convention on Biological Diversity (CBD) High Level Panel estimated the required level of global investment is up to five times as much as present budgets. ${ }^{11}$ On the national scale, for example, a feasibility study of financing instruments undertaken in Honduras for a natural park showed that public financing would cover less than $30 \%$ of the minimum needs of the protected area. ${ }^{12}$ In the South Pacific, the Progress Report for the High Level Panel Meeting of the CBD in 2012 showed that achieving conservation targets requires three to five times more

4. See, e.g., World Database on Protected Areas, PROTECTED PlANET, https://www.protectedplanet.net/c/world-database-on-protected-areas (last visited Apr. 8, 2018); EKO Asset Mgmt. Partners, LlC \& The Nature Conservancy, Investing in Conservation: A LANDSCAPE ASSESSMENT OF AN EMERGING MARKET 40-41 (2014). See generally CREDIT SUISSE AG. ET AL., Conservation Finance: Moving Beyond Donor Funding Toward An Investor-Driven APPROACH 9 (2014).

5. See Nancy Knowlton \& Jeremy Jackson, Beyond the Obituaries, 2 Solutions 1, 1 (2011) (describing conservation successes such as "[s]ea otters and some seabirds, whales, turtles, and fishes ... have increased in numbers.”)

6. See Great Barrier Reef Marine Park Authority, Austl. Gov't, Great Barrier Reef OUTLOOK REPORT 262-64 (2014) (noting that human activity continues to harm the Great Barrier Reef despite regulations designed and enforced by Australia to protect the area).

7. Ilie Marian, Developing Effective Ocean Governance, 4 GEOPOLITICS HIST. INT'L REL. 101, 102 (2012); Shankar Aswani \& Kenneth Ruddle, Design of Realistic Hybrid Marine Resource Management Programs in Oceania, 67 PACIFIC SCI. 461, 463 (2013).

8. Robert Pomeroy \& Fanny Douvere, The Engagement of Stakeholders in the Marine Spatial Planning Process, 32 MARINE POL’y 816, 820 (2008); Kuei-Chao Chang, Conflict Resolutions in the Implementation of Marine Resource Policies, 41 COASTAL MGMT. 150, 150-51 (2013).

9. Sara Monteiro et al., Improving Fishery Law Enforcement in Marine Protected Areas, 1 AEgean Rev. L. SEA Mar. L. 95, 101 (2010).

10. Melissa Bo et al., Marine Conservation Finance: The Need For and Scope Of an Emerging Field, 144 OCEAN \& COASTAL MGMT. 116, 119 (2015).

11. Convention on Biological Diversity, Resourcing the Aichi BIODIVERsity TARgets: AN ASSESSMENT OF BENEFITS, INVESTMENTS AND RESOURCE NEEDS FOR IMPLEMENTING THE STRATEGIC PLAN FOR BIODIVERSITY 2011-2020 (2014), https://www.cbd.int/financial/hlp/doc/hlp-02-report-en.pdf.

12. Nicholas Pascal et al., Instrumentos financieros para la financiacion del Parque Nacional Blanca Jeannette Kawas Fernandez, Honduras, U.N. EnVTL. Program (2013). 
financing than is currently committed. ${ }^{13}$

\section{B. Market Mechanisms as a Solution}

Today, $80 \%$ of biodiversity finance is generated from non-market mechanisms, which primarily come from the public sector and rely on regulations for their implementation. ${ }^{14}$ These include domestic budget allocations, Official Development Assistance (ODA), debt-for-nature swaps, and subsidies reform. The allocation of public finance is primarily a question of political will and public opinion, and therefore tends to vary with political cycles. ${ }^{15}$ Although these mechanisms are expected to scale up in the future, market-based options present great potential for future development.

It is estimated that market-based mechanisms will generate up to $50 \%$ of biodiversity financing for coral reefs in $2020^{16}$, but long-term, reliable mechanisms need to be established in order to ensure continued growth in financing. ${ }^{17}$ Instruments for conservation finance are diverse and several classifications have been proposed. ${ }^{18}$ Instruments might seek to internalize the damage and benefits associated with economic activity based on either the "polluter pays" or "beneficiary pays" principle. Environmental taxes, taxation of contamination, and compensatory measures of impacts (the avoid-reduce-compensate sequence) are examples of market-based public instruments focusing on damages. On the benefits side, tools include payments for ecosystem services (PES), public-private partnerships (PPPs, e.g. concessions, easements), and product sustainability labels.

The CBD and the United Nations Environment Assembly (UNEA) recently recommended exploration of new and innovative financial mechanisms at all levels. ${ }^{19}$ Five areas of private-sector financial innovation have been established: PES schemes; biodiversity offset mechanisms; markets for green products, business-biodiversity partnerships and new forms of charity; and the establishment of new sources of international

13. See generally Nicolas Pascal et al., Private Financing for MPAs: Concrete Experiences, Proceedings of the 3Rd International Marine Protected Areas Congress (2014).

14. Collaborative Partnership on Forests, Advisory Group on Finance, 2012 Study on Forest Financing, http://www.un.org/esa/forests/pdf/cpf-oli/AGF-Study-July-2012.pdf (last visited Apr. 8, 2018).

15. CREDIT SuISSE AG ET AL., supra note 4.

16. See generally Collaborative Partnership on Forests, supra note 14.

17. Forest Trends \& The Katoomba Group, Payments for Ecosystem Services: Getting Started in Marine and Coastal Ecosystems, https:/www.forest-trends.org/wp-content/uploads/ imported/marinecoastal-pes-getting-started_2010-pdf.pdf (last visited Apr. 8, 2018).

18. See CREDIT SUISSE AG ET AL., supra note 4 (arguing that these classifications include "direct conservation strategies ... or linked approaches ... that seek to incentivize private investment through public finance”).

19. Convention on Biological Diversity, supra note 11, at 93-95. 
development finance.

\section{INTRODUCTION TO IMPACT INVESTMENT}

\section{A. Background \& Definition}

The concept that economy and ecology can be mutually beneficial has its roots in the $1970 \mathrm{~s}^{20}$ and evolved in the 1980s to include discussions about sustainable development. ${ }^{21}$ Businesses began reducing environmental damages by engaging in "corporate social responsibility." 22 In the 1990s, the term "triple bottom line" to denote economic, ecological, and social performance became a popular catchphrase among businesses that aimed for more than just financial profits. ${ }^{23}$ Economists refer to the triple bottom line as "utility maximization," where utility can include economic, environmental, and social targets. ${ }^{24}$ Emerson describes blurring the lines between natural, financial, and social capital and aiming for "blended value." 25

The latest iteration in this trend is "impact investing," which has been defined by the Global Impact Investing Network (GIIN) as "investments made into companies, organizations, and funds with the intention to generate social and environmental impact alongside financial return." 26 In this definition and in this article, the term "impact" refers to positive impacts or benefits such as cleaner water, more jobs, or greater protection for species. Unlike corporate social responsibility, which tries to reduce negative impacts of firms' economic activity, impact investing is characterized by the intent to produce net positive environmental or social outcomes. ${ }^{27}$

The impact investing industry is still in its infancy, but is growing

20. Leon C. Braat \& Rudolf de Groot, The Ecosystem Services Agenda: Bridging the Worlds of Natural Science and Economics, Conservation and Development, and Public and Private Policy, 1 ECOSYSTEM SERVS. 4, 5 (2012).

21. WORLD COMM’N ON ENV’T AND DEV., OUR COMMON FUTURE (1st ed. 1987).

22. Tim Hindle, Triple bottom line, ECONOMIST, https://www.economist.com/node/ 14301663 (last visited Apr. 8, 2018).

23. Id.

24. The Triple Bottom Line and Sustainable Economic Development Theory and Practice, Econ. DEV. Q. (Sage J., Thousand Oaks, C.A.), Nov. 2016, at 1, 1.

25. Id.

26. Global Impact Investing Network, Impact InVEsting Trends: Evidence of A GROWING INDUSTRY 55 (2016).

27. J.P. Morgan, Impact InVEstments: An EMERging Asset Class 5 (2010); Antony BuggLevine \& Jed Emerson, Impact Investing: Transforming How We Make Money While Making a Difference, 6 Innovations 9, 10-11 (2011); Paul Brest \& Kelly Born, When Can Impact Investing Create Real Impact?, 11 STAN. SoC. INNOVATION REV. 22, 22-23 (2013). 
rapidly. ${ }^{28}$ One study estimates that the industry will be valued at US $\$ 500$ billion by 2019. ${ }^{29}$ Another study found that impact investors may invest almost US $\$ 4$ billion over the next year. The study expected that five to ten percent of all portfolios will be allocated to impact investments in the next ten years. ${ }^{30}$ Some experts now claim that "impact investing" is distinct from other types of philanthropy and business, and is categorized as a unique subject matter. ${ }^{31}$

Impact investments can be made in both emerging and developed markets, with the majority targeting social and health problems such as poverty, water security, malnutrition, and disease in developing countries. ${ }^{32}$

\section{B. Review of Impact Investing Components}

We begin by reviewing the literature and presenting the participants, investments, and outcomes of impact investments (Figure 1). This review draws from the peer-reviewed literature in business, sustainable development, the social and environmental sciences. It also draws significantly from grey literature, as much of the analysis and literature on impact investing is not published in academic journals. ${ }^{33}$ As impact investments are a heterogeneous group of investments, united only by the intention of investing capital to produce blended value, this review

28. Johanna Mair \& Katherine Milligan, Roundtable on Impact Investing, 10 STAN. Soc. InNOVATION REV. 24, 24 (2012); Eric Nee, Impact Investing Grows Up, 10 STAN. Soc. InNOVATION ReV. 4 (2012); Lester M. SALAmon ET Al., NeW Frontiers of Philanthropy, A Guide to the NEW Tools and Actors Reshaping Global Philanthropy and Social Investing 3-4 (Lester M. Salamon ed. 2014).

29. MONitOR InST., INVESTING FOR SOCIAL \& ENVIRONMENTAL IMPACT 5 (2009).

30. Id. at 16.

31. Bugg-Levine \& Emerson, supra note 27.

32. J.P. MORGAN, supra note 27 , at 7-8.

33. See SALAMON ET AL., supra note 28 (noting that some author collective works, such as "New Frontiers of Philanthropy” looks towards grey literature). 
summarizes a diverse range of investments.

Figure 1: Impact Investing Participants, Mechanisms, and Outcomes. ${ }^{34}$

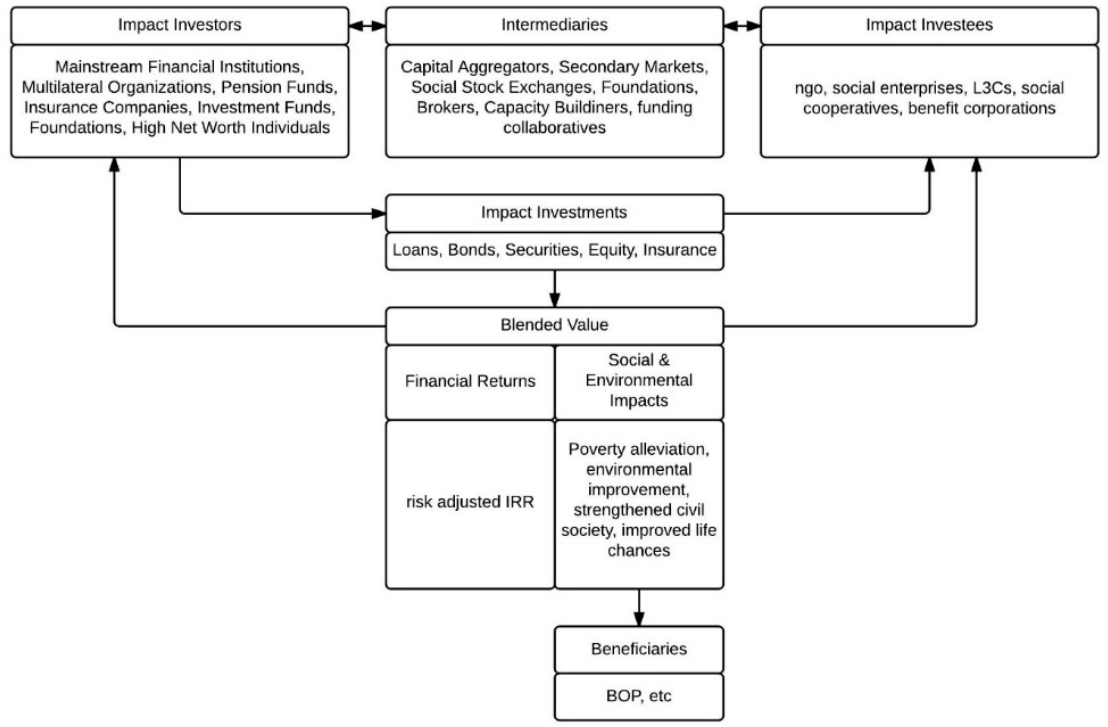

\section{Impact Investors}

Little attention has been given in the literature to the supply side of conservation finance, namely the perspective of investors and their investment approaches. ${ }^{35}$ Impact investors include philanthropic foundations, multilateral organizations (e.g., World Bank), mainstream financial institutions (i.e., large international banks), high net worth individuals, pension funds, insurance companies, and investment funds. ${ }^{36}$ Impact investments have been made on every continent, but investors from the United Kingdom and the United States have a strong presence. ${ }^{37}$

34. See GLOBAL Impact InVESTING NeTWORK, supra note 26.

35. See Ann-Kristin Achleitner et al., Unlocking the Mystery: An Introduction to Social Investment, 6 INNOVATIONS 145 (2011) (determining that more focus should be given to what opportunities are available to investors); Elizabeth Littlefield, Impact Investing: Roots \& Branches, 6 InNOVATIONS 19 (2011) (finding that instead of looking to foreign aid, there should be greater connection with the private sector). See generally LAURA TLAIYE ET AL., WORLD BANK, EXPANDING FINANCING FOR BIODIVERSITY CONSERVATION: EXPERIENCES FROM LATIN AMERICA AND THE CARIBBEAN (2012).

36. See Bugg-Levine \& Emerson, supra note 27.

37. See PCV InSight, CASE At DukE: ImpaCt Assets, IMPACt InVESTing 2.0: The WAY FORWARD (2013) (examining twelve very successful funds uncovered certain commonalities among them, including the finding that much of their resources were coming from the United States and the 
The motivation for investors to make impact investments varies. Some investors approach the industry from a philanthropic perspective, while others view impact investing as more in line with traditional capital markets. Impact investors can be classified into three main categories ${ }^{38}$ : Impact First (primarily seeking to maximize impact while secondarily expecting financial returns); Investment First (fiduciaries primarily seeking market-rate or premium returns and secondarily seeking a positive social or environmental impact); and Catalyst First (primarily seeking to give or invest to help build the impact investing industry and infrastructure).

Investors that have traditionally made philanthropic donations have a growing desire for philanthropy to become akin to capital markets and for philanthropists to obtain the largest returns for their investments. This trend is sometimes termed "philanthrocapitalism" or "venture philanthropy". 39

Given the early stage of development of most investment opportunities in marine conservation, investor profiles in this arena will vary from catalytic first loss to venture capital. Investor targets will include high-net-worth and ultra-high-net-worth (HNW/UHNW) individuals ${ }^{40}$ as well as venture philanthropists. Each group has its own risk-return expectations, liquidity exigencies, investment horizons, ticket sizes, and investment product preferences. Each of them will also require the existence of (or freedom from) a regulatory framework.

\section{Impact Investees}

On the receiving end of impact investments are the "investees." Nonprofit organizations, although traditionally reliant on grants, can accept some forms of impact investments. The most common impact investee is a social enterprise, which is a for-profit company with a social and/or environmental mission. One particular type of social enterprise that is gaining popularity is a benefit corporation (also called "B-Corp"). ${ }^{41}$ Benefit corporations have legal structures that allow them to pursue their missions, even when it

United Kingdom).

38. Early white papers on impact investing written by teams from the Rockefeller Foundation, J. P. Morgan Social Finance, Goldman Sachs, Global Impact Investing Network (GIIN), SRI research by Lloyd Kurtz and Meir Stat- man, Pacific Community Ventures’ Insight and Harvard's Hauser Institute for Responsible Investment, and others provide a basic background for understanding impact investing.

39. Matthew Bishop, Survey, The business of giving: A survey of wealth and philanthropy, ECONOMIST, Feb. 25, 2006, at 1.

40. HNW/UHNW individuals have historically been the investor group most attracted to conservation finance, spearheaded by passionate individuals who have made large donations or investments in conservation assets out of their personal conviction.

41. See generally Wendy Stubbs, Sustainable Entrepreneurship and B Corps, 26 BUS. STRATEGY ENV’T 331 (2017). 
reduces the financial returns to shareholders. ${ }^{42}$ Other types of social enterprises include social cooperatives, community interest corporations (United Kingdom), low-profit limited liability companies (L3Cs; United States), and flexible-purpose corporations (United States). ${ }^{43}$

\section{E. Impact Investment Mechanisms}

Impact investments have been made across several asset classes including debt financing, equity, securities, and loan guarantees ${ }^{44}$

As of 2015, debt accounted for $70 \%$ of impact investment deals. ${ }^{45}$ Loans (one of the types of debt) remain by far the most common impact investing mechanism since they are typically fast to mature and less risky than equity. ${ }^{46}$

A variation of the loan, a loan guarantee allows new investors to make impact investments by reducing the risk-return ratio. ${ }^{47}$ Another variation on loans are social impact or social benefit bonds, which are long-life loans that are only repaid if social impacts are achieved. ${ }^{48}$

There is an active debate about whether impact investments should be considered a new and separate asset class. Some experts

believe that they should, ${ }^{49}$ while others believe that this categorization is dangerously limiting and that impact investments should be made across a range of asset classes. ${ }^{50}$

\section{F. Blended Values}

Generating a financial return (ranging from concessional to competitive

42. Benefit corporations are legally allowed in 27 states in the United States. This new legal structure requires companies to report on material benefits to society from their business activities. The benefit corporation structure allows businesses to accept below market rate of return for their shareholders when positive societal benefits are generated. What is a Benefit Corporation?, B LAB, http://benefitcorp.net/ (last visited Apr. 8, 2018).

43. Bugg-Levine \& Emerson, supra note 27.

44. Id

45. GLOBAL IMPACT INVESTING NETWORK, supra note 26.

46. See SALAMON, supra note 28 (noting that loans are still preferred for their fast maturity and lower risk level).

47. Id.

48. SOCIAL FinANCE, INC., A NEW TOOL FOR SCALING IMPACT: HOW SOCIAL IMPACT BONDS CAN Mobilize PRIVATE CAPITAL TO AdVANCE SOCIAL GOOD, 12 (2012).

49. J.P. MORGAN, supra note 27.

50. See generally Bugg-Levine \& Emerson, supra note 27. 
rates) is typically the major challenge for many proponents of impact investment projects. It is also difficult to demonstrate positive impacts of many management strategies as there are often inadequate baseline data associated with the social and environmental benefits they target.

\section{i. Blended Value: Financial Returns}

By definition, impact investments must create financial returns, but returns can range from highly concessionary (below average market rate of return) to above market rate. ${ }^{51}$ In a survey targeted at impact investors in North America, some investors expected 0-5\% returns over 1-3 years, while others expected upwards of $25 \% .^{52}$ When benchmarked against realized returns by asset class (mainly debt vs. equity) and by market (focusing on emerging vs. developed), the study found that investors sacrificed financial returns for both debt and equity in developed markets, but were competitive with market rates in emerging markets. ${ }^{53}$ Capital preservation (risk) is more central for some impact investors than the anticipated rate of return.

The impact investing industry is still too new to have comprehensive data on financial performance. ${ }^{54}$ Some experts believe that market-rate investments are not impact investments because they do not provide any additional value to the market system. ${ }^{55}$ However, other experts argue that market-rate impact investments can provide additional value through investing in undercapitalized places, sectors, and asset classes. ${ }^{56}$ Here we use the definition based on intention (per the GIIN definition above), which allows for the full range of financial returns to qualify as impact investments.

\section{ii. Blended Value: Social \& Environmental Impacts}

GIIN developed the Impact Reporting and Investing Standards (IRIS) to assist stakeholders in monitoring their social and environmental impacts with standard metrics. The adoption of IRIS metrics is voluntary, and although 120 organizations are registered on IRIS and claim that they use IRIS in some form, many use it in combination with other metrics, claiming that IRIS metrics are not precise enough to capture all environmental benefits. ${ }^{57}$ In a recent survey of environmental impact investing funds, for example, half of the 23 participating funds using IRIS also relied on a third-

\footnotetext{
51. Brest \& Born, supra note 27, at 22.

52. J.P. MORGAN, supra note 27.

53. Id.

54. Id.

55. Brest \& Born, supra note 27, at 60 .

56. Bugg-Levine \& Emerson, supra note 27, at 13-14.

57. GLOBAL IMPACT INVESTING NETWORK, supra note 26.
} 
party to measure environmental impact. ${ }^{58}$

\section{G. Challenges}

Recent works on impact investment have identified several challenges to the continued growth of impact investing. ${ }^{59}$ Priorities for future efforts in the impact investing field include:

\section{Investment sizes:}

Investment sizes are typically smaller than institutional investors' minimum investment size, but larger than many individual impact investors' desired allocation. In the same way, there is a lack of innovative deal/fund structures consolidating projects and accommodating investors' needs.

\section{Shortage of high quality investment opportunities with track records:}

Many NGOs are doing credible work around policy and capacitybuilding, but few of these organizations are developing a pipeline of investment opportunities.

\section{Common Standards and Metrics:}

Shifting from "anecdotal stories" to standards is necessary to make results more transparent and accountable, benchmark projects against one another, and attract a wider audience of investors.

\section{Risk Mitigation Approaches:}

The risk-return relationship of conservation projects must become more attractive for investors through a combination of strategies to de-risk investments.

\section{Niche and Boutique Strategies:}

Even if the investment market is seeking consolidated projects that can be scaled with attractive risk-return profiles, a market for niche and boutique investment projects should be considered.

58. Id. at 17.

59. See generally ALtHELIA ECOSPHERE, INVESTING FOR IMPACT AND VALUE IN THE MARINE ENVIRONMENT (2016); Santiago Cortes, Highlights from White House Roundtable on Conservation Finance, CONSERVATION FINANCE NETWORK (Feb. 15, 2017), https://www.conservationfinancenetwork.org/2017/02/15/highlights-from-white-house-roundtable-onconservation-finance. 


\section{MARINE IMPACT INVESTMENT: TRACK RECORD AND CHALLENGES}

\section{A. Impact investment in conservation}

A small but growing proportion of impact investments focus on environmental impacts. For example, a recent study backed by JP Morgan and The Nature Conservancy estimated that US\$8.2 billion has been invested in conservation efforts since 2004. ${ }^{60}$ The report found that investors committed US\$1.6 billion in capital from 2014 to 2015, double the average annual commitments between 2009 and 2013. ${ }^{61}$

A 2016 report by Credit Suisse and McKinsey Center for Business and Environment estimated that up to US\$200-400 billion between 2016 and 2020 might be invested in conservation finance. ${ }^{62}$ The report also revealed at least US\$3.1 billion in committed capital, still on the sidelines, awaiting attractive deals in food and agriculture, habitat protection, clean water initiatives, and other conservation projects. ${ }^{63}$

Experts claim that even though the pipeline of projects has significantly increased, investors are holding back since the expected returns are not worth the risk. ${ }^{64}$ Experts further suggest that while there have been some successes with private financing in conservation, "overall investment volumes have been small, adequate returns have not always been achieved, and the knowledge required to build scalable investment products is dispersed." 65 Therefore, a concerted, systematic effort focused on creating investment products that provide both conservation and financial returns is necessary.

Private investment in marine biodiversity and ecosystem services is in an early stage of development, and practical experience is very limited. ${ }^{66}$ While there are numerous examples of impact investments in terrestrial environments, such as those focusing on watershed and forest ecosystem services, ${ }^{67}$ initiatives focusing on marine ecosystems are rare and not well documented. ${ }^{68}$

60. EKO Asset Mgmt. Partners, LLC \& The Nature Conservancy, supra note 4, at 9.

61. Id.

62. CREDIT SUISSE AG ET AL., supra note 4, at 10.

63. Kelley Hamrick, State of Private Investment in Conservation 2016, A Landscape Assessment of an Emerging Market, J.P. MoRGAN, https://www.jpmorganchase.com/corporate/ CorporateResponsibility/document/cr-es-investment-in-conservation-report-2016.pdf (last visited April 17, 2018).

64. See Cortes, supra note 59 (referencing a discussion at the White House focused partially on risk mitigation tools).

65. Id.

66. See generally Forest Trends \& The Katoomba Group, supra note 17.

67. See generally J.P. MORGAN, supra note 27.

68. Melissa Bos et al., Marine Conservation Finance: Need for and scope of an emerging field, 114 OCEAN \& COASTAL MGMT. 116, 128 (2015). 
Impact investments are following the early-stage development of several sectors of the "blue" or ocean-based economy (see Figure 2) ${ }^{69}$ Ecotourism (including habitat protection) and sustainable fisheries have been identified as primary candidate industries for impact investments. ${ }^{70}$

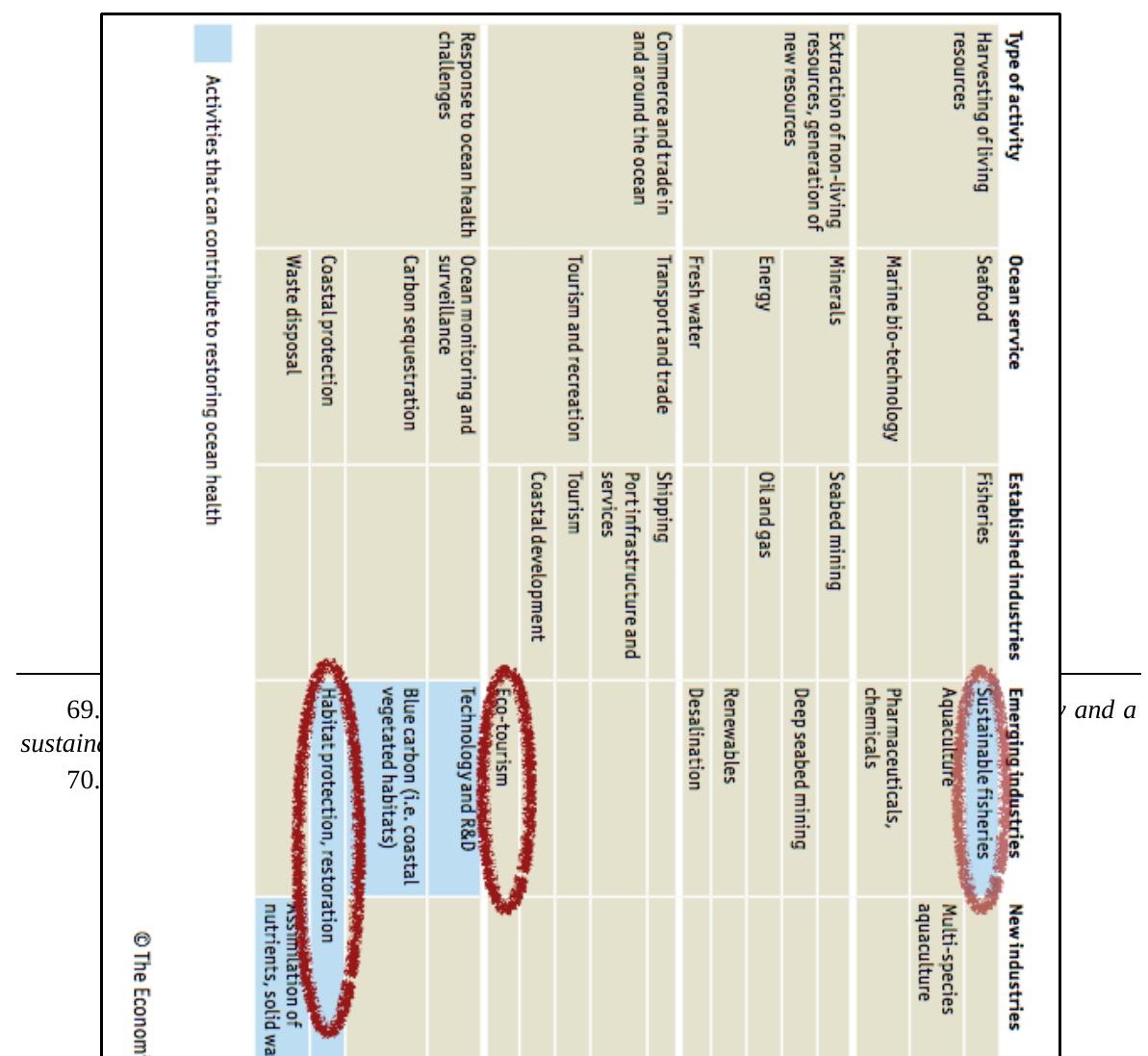


Figure 2: Components of the blue economy (modified from The Economist Intelligence Unit, 2015). ${ }^{71}$ Circles indicate candidate industries for impact investment.

\section{B. Marine protected areas and eco-tourism}

One of the primary investment vehicles in marine conservation is the Entrepreneurial Marine Protected Area (EMPA). ${ }^{72}$ An EMPA is a management area that is primarily supported by a profit-bearing business model, typically associated with nature tourism. ${ }^{73}$ EMPAs are considered marine impact investments because they are designed to produce positive environmental and social impacts, and they primarily employ business models instead of grants to achieve those outcomes. While many terrestrial protected areas have private sector involvement, ${ }^{74}$ significantly fewer MPAs include the private sector. ${ }^{75}$

Recent work conducted by Bush, et al. showed that entrepreneurial intervention in EMPAs have included collecting diver fees that directly funded park management, designing and implementing co-management

71. Economist Intellegence Unit, supra note 69.

72. CREDIT SUISSE AG ET AL., supra note 4, at 16.

73. Simon R. Bush ET AL., SUSTAINABLE ENTREPRENEURSHIP AND SOCIAL INNOVATION 124-29 (Katerina Nicolopoulou et al. eds., 2015).

74. Philip Dearden et al., Trends in Global Protected Area Governance, 1992-2002, 36 ENV’L MGMT. 89, 89 (2005).

75. See discussion infra Part V. 
arrangements in state-designated parks, and establishing varying degrees of private tenure over marine habitat. ${ }^{76}$ While the specific drivers for private sector involvement differ by case, one constant challenge for EMPAs has been maintaining a requisite level of legitimacy and authority to practice conservation.

Pascal et al. argued that the economic feasibility, ecological effectiveness, and socio-cultural implications of EMPAs require further investigation. ${ }^{77}$ However, Svensson, Rodwell et al. assessed a "hotelmanaged" MPA in Vietnam and found that the EMPA was producing similar ecological results as non-private MPAs, but that the benefits were localized to a small area. ${ }^{78}$ De Groot and Bush investigated two EMPAs in Curaçao that have the potential to regulate diver behavior and reduce damage to coral reefs, but were constrained in efficacy by market competition and a lack of authority to manage. ${ }^{79}$ Bottema and Bush used two examples in Indonesia Yayasan Karang Lestari and Gili Trawagan - to argue that EMPAs can be durable, but also highlighted concerns about the private sector pushing out traditional owners. ${ }^{80}$

A comparison of three EMPAs in Indonesia, Belize, and Tanzania showed that a similar role is played by the entrepreneurs in each case in establishing and consolidating EMPAs. ${ }^{81}$ The entrepreneurs involved in these cases are similar in at least three ways: they all seek to establish business opportunities motivated by and dependent on conservation outcomes; are all involved in a globally expanding tourist industry; and are all dependent on social and political relations with government, civil society groups, and local communities. The entrepreneurs in these cases brought both economic and non-economic value to individuals as well as noneconomic value to society by establishing a system of usage rights for the ecosystem resources protected by the EMPAs. ${ }^{82}$

76. BUSH ET AL., supra note 73.

77. See Nicholas Pascal et al., Impact Investing for Ocean Health: opportunities and challenges, 6 SOLUTIONS J. 49 (2015).

78. Patrik Svensson et al., Privately Managed Marine Reserves as a Mechanism for the Conservation of Coral Reef Ecosystems: A Case Study from Vietnam, 38 AMBIO 72, 77-78 (2009).

79. Jiska de Groot \& Simon R. Bush, The Potential for Dive Tourism Led Entrepreneurial Marine Protected Areas in Curacao, 34 MARINE POLICY 1051, 1057 (2010).

80. See BUSH ET AL., supra note 73.

81. Id.

82. See Thomas Dean \& Jeffery McMullen, Toward a Theory of Sustainable Entrepreneurship: Reducing Environmental Degradation Through Entrepreneurial Action, 22 J. BUS. VENTURING 50 (2007) (arguing that profit maximization and environmental protection can go hand-in-hand). 


\section{Track record of impact investment in protected areas}

We present a list of protected areas co-managed with the private sector and linked to the tourism sector, with discussion of a select few. Terrestrial parks are included alongside marine parks to provide an older track record of impact investment in protected areas. The selection comes from direct observations, exchanges with practitioners, investment brokers including Conservation Capital Inc. and Encourage Capital, and a literature review. The investment mechanisms, impact returns, and financial structures of these case studies can benefit current investors by informing their investment review process.

Marine Parks:

- El Nido-Taytay Protected Area, Philippines

- The Bonaire National Marine Park, Bonaire

- Blue Hole Natural Monument and other PAs, Belize

- Chumbe Island Coral Park, Tanzania

- The Soufriere Marine Management Area, St. Lucia

- Pemuteran, Indonesia

- Misool Eco-dive Resort, Indonesia

- Komodo National Park, Indonesia

- Whale Island Resort, Vietnam

Terrestrial Parks:

- The Mara Conservancy, Kenya

- US National Parks

- African Parks network

- The Loisaba Wilderness, Kenya

- Kakum National Park, Ghana

- Chuilexi Conservancy, Mozambique

Three of the marine parks require a closer look.

\section{El Nido-Taytay Protected Area, Philippines:}

El Nido-Taytay Managed Resources Protected Area demonstrates the potential of a PPP mechanism. Here, a developer (the Ten Knots Development Corporation) built a series of exclusive island resorts over 20 years, a pioneering tourism concept in the Philippines. Award-winning tourism services are combined with effective environmental management and community service. The developer's efforts to create a marine park have 
resulted in the relative protection of the nearby Bacuit Bay-a unique landscape of limestone cliffs with azure bays and white sandy beaches.

\section{Bonaire National Marine Park:}

Stichting Nationale Parken Bonaire (STINAPA) is the nongovernmental organization (NGO) responsible for managing the Bonaire National Marine Park (established in 1979), which encircles the Caribbean island of Bonaire from the high water mark out to 200 feet in depth. It differs from many other MPAs in that it is not managed by the government, but by the NGO. STINAPA has a contract with the government to manage the Park, entailing enforcement, education, maintenance, and research activities. The Park is financed solely via user fees, and legislation requires that user fee revenues can only be used for Park management. Revenues from SCUBA diving and other user activities total US\$1.2M per year. At this time, the Park is financially sustainable.

\section{Blue Hole Natural Monument and other Protected Areas, Belize:}

In 1996, the Belize Audubon Society signed a Memorandum of Understanding with the Government of Belize to manage six protected areas. In 1999, the Memorandum was extended to include two new protected areas, Blue Hole and Victoria Peak Natural Monuments. The NGO now manages seven protected areas and has more than 40 full-time staff. Entrance fees from the more than 40,000 annual visitors cover $60 \%$ of the operating expenses, which totaled US\$1.2M in 2016. The company possesses more than US\$2M in assets (buildings, properties, vehicles) and US\$1.4 in an endowment fund (from a debt for nature swap realized in 2001).

\section{III.THE BLUE FINANCE PROJECT}

\section{A. General approach}

The Blue finance initiative's primary activity is to design and implement impact investments for the conservation of marine biodiversity. A suite of investments is being developed in the Caribbean (Antigua \& Barbuda, Bahamas, Barbados, the Dominican Republic, and St. Kitts \& Nevis) where Blue finance is partnering with government, key actors, and investors to ensure sustainable financing and efficient management for 
MPAs. The MPAs are expected to restore the coastal biodiversity of the islands and bring green opportunities for economic development to the countries.

Blue finance is a collaborative initiative between the NGO Economics for Coral Reef Ecosystems (ECRE) and the United Nations Environment Program (UNEP) through its Global Coral Reef Partnership. In the Caribbean, the Regional Activity Centre for the Protocol on Specially Protected Areas and Wildlife for the wider Caribbean (SPAW-RAC) of the Caribbean Environmental Program (CEP) is the main implementing agency.

To pursue its objective, the initiative has drawn on existing guidance and methodologies for economic instruments and other relevant non-public funding mechanisms that have been successfully applied in terrestrial settings. The initiative has adapted these instruments to address the particular requirements and needs of the coral reef environment and related ecosystem service uses. In particular, financing requirements for marine conservation were evaluated on the basis of investment and resources needs, using the Biodiversity Finance Initiative (BIOFIN) methodological approach. ${ }^{83}$ In parallel and drawing on UNEP guidance ${ }^{84}$, Blue finance identifies the main beneficiaries of ecosystem services as well as the underlying cash flows. In that approach, Blue finance has followed methodologies described in recent works by the TEEB initiative and the UNEP Ecosystem Services Economics Unit. ${ }^{85}$ This is the preliminary step in the establishment and monitoring of the financial instrument that represents the primary efforts of the project.

The project has based its implementation strategy on the recommendations and approaches described in several studies regarding the establishment of economic instruments, ${ }^{86}$ the creation of tourism concessions $^{87}$ and the establishment of PPPs. ${ }^{88}$ The identification of investment opportunities has also relied on the findings of the Barbados green economy scoping study that identified greening opportunities in different economic sectors, including fisheries and tourism. ${ }^{89}$

83. UNDP. 2014. The BIOFIN Workbook: A Tool to Mobilize Financial resources for Biodiversity and Development. New York: United Nations Development Programme. Available at www. biodiversityfinance.net (last visited Apr. 9, 2018).

84. See Int'l Union for Conservation of Nature, The Futures of Privately Protected Areas, https://portals.iucn.org/library/sites/library/files/documents/PATRS-001.pdf (last visited Apr. 8, 2018) (within this report are UNEP guidelines).

85. Id.

86. Forest Trends \& The Katoomba Group, supra note 17.

87. Thompson, A., Massyn, P.J., Pendry, J., Pastorelli, J. 2014. Tourism Concessions in Protected Natural Areas: Guidelines for Managers. United Nations Development Programme.

88. Int'l Union for Conservation of Nature, supra note 84

89. Forest Trends \& The Katoomba Group, supra note 17. 
The Blue finance initiative expects to restore marine and terrestrial biodiversity, improve tourism attractiveness, and create significant job opportunities in the tourism, fishery and agro-forestry sectors. The project primarily addresses Sustainable Development Goal (SDG) no. 14 (life below water) but also contributes to SDG no. 1 (no poverty), no. 5 (gender equality), no. 8 (decent work and economic growth) and no. 13 (climate action) through the mobilization of financial resources for effectively implementing the management plans for integrated coastal management.

Blue finance identified PPP agreements as an effective means of comanaging MPAs with the private sector. The private sector is expected to provide the majority of required funds to improve and manage the area, and receive a return on investment mainly through user fees and innovative tourism products. The main advantages of PPPs include their flexibility to set fees and charges; their ability to establish funding mechanisms such as concessions, respond to customer needs, and retain the money they earn (which provides an incentive for greater entrepreneurship); and their freedom to implement staffing policies based on efficiency and market salaries. ${ }^{90}$

\section{B. The PPP agreement}

Blue finance proposes to place the MPAs under co-management through a PPP agreement with a non-profit co-management company and the public sector. The PPP agreement will be memorialized in a contract that outlines the responsibilities of each party and clearly allocates risk. The agreement document will stipulate the responsibilities of both the public and private sectors within the MPA and be negotiated by both parties. The agreement is initially for 10 to 15 years and is renewable.

The co-management company is expected to be a non-profit Special Purpose Entity (SPE) governed by local stakeholders. Locally-based NGOs, hoteliers, tourism businesses, HNW individuals, fisher cooperatives and local communities are expected to become members. The SPE will be responsible for the implementation of activities related to the enhancement of marine ecosystems, including improving health and monitoring, zonation of activities and compliance, community engagement, livelihood enhancement, and support to sustainable tourism activities. The SPE will receive a mandate to charge user fees to anyone entering the MPA.

The government will maintain its core functions and be responsible for regulation and enforcement of uses and zonation, the set-up of user fees and

90. U.N. Env'l Programme, The Blue Finance Project: An example of public-private partnership, https://bluesolutions.info/images/Public-Private-Partnership-Blue-Finance-an-example.pdf (last visited Apr. 8, 2018). 
maintenance of specific on-shore facilities. The functions and staff of public agencies (e.g. Coast Guard, Marine Police, Fisheries, Environment and other government agencies) will be maintained and their work continued.

A Stakeholders Advisory Committee (SAC) will be established to participate in the co- management, which will provide regular inputs into the zoning, management, uses and enforcement process. Its membership will include government agencies, tourism associations, local communities, fisherfolk, hoteliers, developers, research institutions, NGOs, civil society and the boating community.

\section{i. Primary up-front investments will cover the purchase or restoration of a visitor center, vessels, vehicles, signage and equipment.}

The investments will be structured through a loan agreement with the non-profit SPE responsible for co-managing the MPA. The funds will be used mainly to finance the up-front capital expenditures.

Revenue streams will be generated from statutory visitor fees and innovative tourism activities. For instance, a growing market opportunity has been identified for activities that provide discovery of the underwater world for visitors without water immersion.

\section{Expected impacts and returns}

The MPAs are expected to improve coral reef ecosystem health, including trophic structure, biodiversity, and resilience. Indicators on live coral cover, fish population density, and species diversity will be monitored to verify the effects on ecosystem health. The improvement in ecosystem services provided by coral reefs (e.g. fish biomass for fisheries, scenic beauty for tourism, coastal and beach protection for real estate) are expected to have a direct impact on local economies. Local communities of small-scale fishers will benefit annually from the new income-generating activities in the MPAs, as well as increased fishery productivity. The MPAs will also provide new opportunities for small-scale eco-tourism activities.

Financially, the projects will offer a minimum $8.5 \%$ internal rate of return (IRR) to impact investors. The up-front investments are carried out during the start-up phase of the co-management activity (expected to last the first two years). They include the purchase and/or restoration of the physical assets of the MPA and preliminary studies. The typical capital expenditures for the MPAs are approximately US $\$ 3.5 \mathrm{M}$ with an investment spread over a two-year period.

Returns are based on income projections and target market size estimates. The target markets of each project are consolidated and dynamic: 
the Caribbean region received annually more than 1 million visitors in 2016 and has an annual average growth of over $3 \%$ since 2008. ${ }^{91}$ Annually and in each country, almost 100,000 visitors are already using the MPAs through diving or day-tour excursions and will pay the user fees as soon as the comanagement is established. Annual revenue is expected to be close to US $\$ 1.5 \mathrm{M}$, covering operational expenditures and debt paybacks.

\section{IV.CONCLUSION}

The marine environment has very few practical experiences with mechanisms to finance biodiversity through impact investment. As such, one of the primary priorities for the near future is to provide empirical evidence of how non-public funding mechanisms can support marine conservation.

PPPs can be part of the solution. By linking government and private sector finance through agreements that allow sharing of funding, expertise, and access to technology and resources, PPPs can leverage significant new funds for, and interest in, marine conservation. The Blue finance initiative provides one model of a PPP agreement for marine conservation that outlines the responsibilities of each party and clearly allocates investment and risk. This approach, though still in proof of concept, is expected to reduce the financial burden on the public sector and bring an entrepreneurial approach to managing MPAs.

91. Caribbean Tourism Org., Caribbean Tourism Review, (Feb. 11, 2014) https://www.onecaribbean.org/wp-content/uploads/2014TourismReviewDocumentAmended FEB11.pdf. 